\title{
Prevalence of detection of visual impairment and treatment in the age group 4 to 7 years
}

\author{
Detecção da prevalência de baixa visual \\ e tratamento no grupo etário 4 a 7 anos
}

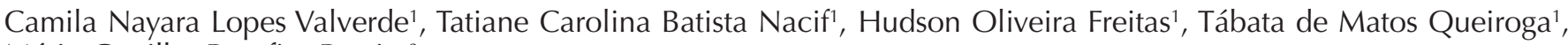
Mário Genilhu Bomfim-Pereira²

\begin{abstract}
Objective: To determine the prevalence of low vision in a fraction of the students in public schools at Caratinga, Minas Gerais. Moreover, show the relevance of preventive measuresto evaluate Visual Acuity (VA) in children up to 7 years old. Methods: A transversal study was made in students, between 4 and 7 years old, enrolled in first and second year of elementary school of Geraldo Marques Cevidanes Municipal School, in the city of Caratinga, Minas Gerais.VA was evaluated using Snellen optometric chart and considered normal when higher than 0,7. Students who had difficulty in being evaluated or had presented VA less than 0,7 were referred to an ophthalmologist. Results: One hundred-eighteen children were evaluated. Five percent (5\%) of the sample had low VA, being 16,6\% only in the left eye, $33,3 \%$ in the right eye and $50 \%$ bilateral. 66,6\% of students with visual impairment required the prescription glasses. Conclusion: This study meets national research regarding the prevalence of low VA, however, doesn't match with others studies. It is suggested that projects to prevent eye health in children are important not only medically, but also socially.
\end{abstract}

Keywords: Visual acuity; School health; Eye health; Visual disorders; Child

\section{ReSUMO}

Objetivos:Verificar a prevalência da baixa visual numa fração dos estudantes matriculados na rede pública municipal de Caratinga, Minas Gerais, bem como mostrar a importância da realização de ações precoces no cuidado com a acuidade visual (AV) em crianças de até 7 anos de idade. Métodos: Estudo transversal realizado em alunos, com idade entre 4 e 7 anos, matriculados no primeiro e segundo ano do Ensino Fundamental da Escola Municipal Geraldo Marques Cevidanes, do município de Caratinga, Minas Gerais. A AV foi avaliada com base na aplicação do Teste de Snellen e considerada normal quando superior a 0,7. Os alunos que apresentaram dificuldade no exame igual ou inferior a 0,7 foram encaminhados a consultas oftalmológicas. Resultados: Foram avaliadas 118 crianças. Quanto à $\mathrm{AV}, 5 \%$ da amostra apresentou alteração da $\mathrm{AV}$, sendo $16,6 \%$ com alteração visual apenas no olho esquerdo; $33,3 \%$, somente no olho direito; e $50 \%$, bilateral. Necessitaram da prescrição de órteses $66,6 \%$ dos estudantes com baixa visual. Conclusão: Este estudo vai ao encontro de pesquisas nacionais no que tange à prevalência de baixa AV, entretanto discorda de trabalhos que encontraram prevalências destoantes. Sugere-se o desenvolvimento de projetos em saúde preventiva que abranjam a idade escolar não apenas de forma médica, mas também social.

Descritores: Acuidade visual; Saúde escolar; Saúde ocular; Transtornos da visão; Criança

\footnotetext{
${ }^{1}$ Medicine School, Centro Universitário de Caratinga, Caratinga, MG, Brazil. ${ }^{2}$ Setor de Plástica Ocular, Núcleo Avançado de Caratinga, Caratinga, MG, Brazil. This study was carried out at Centro Universitário de Caratinga, Caratinga, MG, Brazil. The authors declare no conflicts of interests.

Received for publication 05/03/2016 - Accepted for publication 11/06/2016
} 


\section{INTRODUCTION}

$\mathbf{S}$ ight is fundamental to the establishment of the relation between man and the world ${ }^{1}$. The development of learning in humans is intrinsically related to sensory information received through sight. Therefore, the integrity of such a sense is essential to learning and socialization of children².

Until school age, visual deficiencies may not be detectable by parents and family members, but not always they are individualized after manifestations of learning difficulties - a key role played by the teacher, allowing early detection, and thus preventing school failure and development of interpersonal and professional strife 3 .

It is essential to combat and identify early visual changes, as until 7 years of age the child is in full visual development ${ }^{4}$. Common causes of low visual acuity respond appropriately to early interventions, such as amblyopia, strabismus, hypermetropia, astigmatism and myopia ${ }^{5}$.

The recognition of visual problems and alert the ophthalmologist are recommended by the World Health Organization (WHO); ametropies are among the five priorities of the world body. For public health, the visual screening test in schools is financially viable and has a high sensitivity $(87.1 \%)^{2}$. Comparisons between the evaluation of visual acuity by Snellen and Photoscreening as screening methods for school children reveal high concordance. However, when considering the high cost of the device and the ease and low cost of using the Snellen charts, it becomes a viable alternative for the detection of visual disorders in children, being able to identify the visual acuity ${ }^{6}$.

The present project makes use of the ease of dealing with visual acuity during childhood, and uses this approach in order to prevent future damage that could generate bigger problems. In this sense, it also takes into account points that go beyond the burden of optical corrections. In addition to the visual damages, the lack of follow-up and early corrective measures may generate costs to the municipal management, arising from future medical appointments, professional management for patient care and, especially, consequences arising from the lack of opportunities that low visual acuity can generate ${ }^{4}$.

The importance of early detection of ametropies and their treatment, as well as amblyopia, is directly linked to public spenses. Early detection of amblyopia generates savings of approximately US $\$ 60,000$ for each 1,000 children. In addition, early identification of these visual impairments promotes an indirect cost savings, because the more the children early diagnosed with eye problems and thus treated, the lower the number of students who will require special programs and care at school. Furthermore, it generates improved learning, greater job opportunities in the future, and lower chances of accidents in the healthy eye $\mathrm{e}^{7,8}$.

According to $\mathrm{WHO}^{9}$, approximately $12,800,000$ children aged from 5 to 15 years present uncorrected refraction errors, being it the main cause of reduced visual acuity during childhood. The tracking proposed is intended to provide to all students who faced changes in the eye health a diagnosis and treatment of the problem found.

The preventive-interventionist bases of the project is the natural development of the study of various campaigns developed by the Brazilian Council of Ophthalmology, such as "Veja bem", "Olho no Olho" e "Olhar Brasil". The peculiarity presented herein makes it possible for the population (the select group formed by students from 4 (four) to 7 (seven) years enrolled in municipal public schools of Caratinga - MG) to treat better the changes found, and guarantees the perennial nature with measures that promote the correct school development. The donation of glasses after ophthalmologic prescription will insert the student into society, providing better sight, and mainly improving their quality of life.

The goal of this study was to verify the visual acuity in a fraction of the students enrolled in municipal public schools in Caratinga - MG with the use of the Snellen chart, which was applied by students of the 10th (tenth) period of the Medicine School at Centro Universitário de Caratinga (UNEC). Students with visual changes of ocular refraction were referred to appointment with an ophthalmologist accredited to the public health system, and received prescription and glasses donated by the government for optical correction, according to the professional evaluation.

\section{Methods}

It is a prevalence study conducted in the period of one day in the second semester of 2015 aiming at detecting visual impairment based on application of the Snellen test in children of both sexes aged between 4 and 7 years old enrolled in the first and second years of elementary school at Escola Municipal Geraldo Marques Cevidanes of Caratinga, Minas Gerais (MG).

The research project was reviewed and approved by the Research Ethics Committee of Centro Universitário de Caratinga (UNEC), under number CAAE 51200415.3.0000.5114.

The total number of students enrolled under the conditions proposed by the study was de166, but 16 were not present on the application day, and 32 students did not bring their informed consent (TFCC) signed. Because of the losses, the final sample was 118 , emphasizing that all children evaluated had previous authorization from their parents or legal guardians with the informed consent signed.

The age of the children in this study was collected from a list with the names and dates of birth of each one of them provided by the school secretariat responsible for the students data.

The application of the Snellen test was carried out by Medicine students from UNEC and supervised by an ophthalmologist and professor at UNEC. The students were previously instructed about the test of visual acuity.

The Snellen scale used comprised only lines with letters "E" positioned in different directions and with decreasing scales in size, once most kids in the study were in the process of literacy.

The test was performed in a classroom that was six meters long and six meters wide. The test environment was silent and with good lighting. The desk that the child sat during the examination was six metres from the Snellen scale, which was fixed on the wall at the height of the eyes of the child ${ }^{1}$. Each child was evaluated individually and separately from the other children, which waited outside the room to be called to perform the test.

After the child sat in the chair, one of the members of the present study occluded the left eye of the child being evaluated with an occluder, thus testing the visual acuity of the right eye. Then, there was an inversion. Children wearing glasses were examined with them.

The test results were considered normal when visual acuity (VA) was higher than 0.7 . Thus, students who have difficulty in the exam equal to or less than 0.7 were sent to ophthalmologic 
appointment for a better analysis of the visual deficit. However, in order to reduce the chance of unnecessary referrals due to children's lack of concentration at the time of the exam, another member of the present study assessed them with a retest. According to the test detection and specialized care, children who required treatment received glasses. The medical appointments and orthotics were provided by city of Caratinga, MG, partner of this study.

After appointment with an ophthalmologist accredited by the city, the members of the present study received the refraction and visual acuity of the patients who were referred to the professional. The information of these data was important for the analysis and comparison of the most common visual problems during childhood.

Leaflets were delivered according to the test result. When the VA was less than 0.7 , the child received the leaflet with the time for the ophthalmologic appointment. If the orthotics prescription was necessary, the student received a leaflet indicating to wear glasses. When eye problems were detected, but the glasses were not the main treatment nor indicated, the student received another leaflet. When the VA was greater than or equal to 0.7 , the child received the leaflet explaining that the student had good vision ${ }^{10}$.

\section{RESULTS}

The visual acuity test assessed 118 children (100\%), 85 of which attending the first year of elementary school, and 33 the second year. In relation to age, $.4(3.4 \%)$ children were 4 years old; 44 (37.3\%), 5 years; 43 (36.5\%), 6 years; and 27 (22.8\%), 7 years, in which the average age was 5.8. In relation to gender, 66 (56\%) children were female; and 52 (44\%), male.

From the sample studied, $6(5 \%)$ children presented visual acuity deficit. Of this group, $1(16.6 \%)$ student only in the left eye (LE); $2(33.3 \%)$ students only in the right eye (RE); and $3(50 \%)$ children with bilateral visual change. The visual deficit regarding boys was $66.6 \%, 4$ children. In relation to girls, the number was $33.3 \%, 2$ students.

Of the $118(100 \%)$ children, $5(4.2 \%)$ needed to repeat the test by another member of the study, and only 1 child really showed visual deficit.

Of the $6(5 \%)$ students referred to ophthalmologic appointment, 3 already wore glasses, 1 had strabismus, and 2 showed visual deficit, one of them due to congenital cataracts and hyperopia and the other due to hyperopia. No child referred to ophthalmic appointment was 4 years old, 1 was 5 years $(16.6 \%)$, only 1 was 6 years $(16.6 \%)$; and 4 were 7 years $(66.6 \%)$. Only $1(16.6 \%)$ was absent. The other $5(83.3 \%)$ children went to the appointment, and $4(66.6 \%)$ of them required an orthotics prescription (Table 1).

All students requiring orthotics were greeted by this partnership with the Health Department of the city of Caratinga, MG. In the end, the glasses were distributed in an individual way.

\section{DISCUSSION}

This study showed that the prevalence of visual deficit in males is larger when compared to females. It is close to the research $^{2}$, although there was no statistical significance in this one $(p>0.15)$. On the other hand, another study ${ }^{11}$ obtained data
Table 1

Results and conduct of ophthalmologic appointment

\begin{tabular}{lccc}
\hline & Age (years) & Right eye & Left eye \\
\hline Patient 1 & 5 & $\begin{array}{c}+0.50,-2.00,0^{\circ}, \\
\text { eyepatch } 1 \text { day }\end{array}$ & $\begin{array}{c}-0.75,15^{\circ}, \\
\text { eyepatch } 5 \text { days }\end{array}$ \\
Patient 2 & 6 & - & - \\
Patient 3 & 7 & $\begin{array}{c}+3.25,-0.75,10^{\circ} ; \\
+6.25,-0.75,10^{\circ}\end{array}$ & $\begin{array}{c}\text { Counterweight, } \\
\text { executive bifocals }\end{array}$ \\
Patient 4 & 7 & $+0.75,-0.25,25^{\circ}$ & $+0.50,-0.50,168^{\circ}$ \\
Patient 5 & 7 & $-1.50,-0.25,140^{\circ}$ & $-1.50,-0.50,145^{\circ}$ \\
\hline
\end{tabular}

in which the females had 2.3 times more chances of visual acuity deficit when compared to females.

In total, 6 (5\%) children were detected with visual change, which agrees with the research ${ }^{11}$, showing $6 \%$ of low visual acuity in the sample. However other studies ${ }^{1,3,4,12}$ found results, respectively, of $11.4 \%, 12.41 \%, 18.1 \%$ and $19.04 \%$, which are far from the value obtained in this study.

With the data obtained, we could see that they correlate with other researches regarding the age of 7 years old, having the largest number of referrals to the ophthalmologist and need for glass prescription. The research reinforces such result ${ }^{3}$.

A unique feature of the present was the guarantee that children needing specialized care and orthotics would receive them for free. This concern was due to the study ${ }^{3}$, which lost $4.57 \%$ of children detected with low visual acuity because they did not attended the ophthalmologic appointment. This study had a loss of $0.8 \%, 5.7$ times lower when compared to study ${ }^{3}$.

\section{CONCLUSION}

This study highlights the importance of early detection of low visual acuity in children under 7 years of age. In addition to the academic base, it was based on social help to children.

Therefore, promoting health an especially visual health is essential and necessary both for prevention and cure. But for the results to be more efficient with less public expenses, as already described in this study, projects aimed at preventive health and covering the children as a whole are needed, with the construction of strategies for visual health improvement.

\section{ACKNOWLEDGEMENTS}

To the Education and Health Departments of Caratinga, Minas Gerais, by granting access to students of public school and collaboration with the distribution of glasses.

To the administrative secretariat and teachers of Escola Municipal Geraldo Marques Cevidanes for assisting in the realization of this study, for making room for the application of the Snellen test, and for facilitating the contact with the students of this study.

\section{ReferenCes}

1. Coelho AC, Dias IM, Reis VN, Salvador M, Pacheco ZM. Olho vivo: analisando a acuidade visual das crianças e o emprego do lúdico no cuidado de enfermagem. Rev Enferm. 2010; 14(2):318-23. 
2. Neves FB, Bitencourt AG, Oliveira PL, Santos LS. Acuidade visual de escolares em comunidade rural da Bahia: uma atividade depromoção de saúde. Gaz Méd Bahia. 2011;81(1):10-3.

3. Fialho FA, Dias IM, Nascimento L, Salvador M, Pacheco ZM. A enfermagem avaliando a acuidade visual de estudantes do ensino fundamental. Rev Baiana Enferm. 2011;25(1):33-40.

4. Silva CM, Almeida DR, Bernardes RR, Bazzano FC, Mesquita Filho M, Magalhães $\mathrm{CH}$. Desempenho escolar: interferência da acuidade visual. Rev Bras Oftalmol. 2013;72(3):168-71.

5. Toledo CC, Paiva AP, Camilo GB, Maior MR, Leite IC, Guerra MR. Detecção precoce de deficiência visual e sua relação com o rendimento escolar. Rev Assoc Med Bras. 2010;56(4):415-9.

6. Sousa RL, Funayama BS, Padovani CR, Schellini SA. Comparação entre acuidade visual e photoscreening como métodos de triagem visual para crianças em idade escolar. Rev Bras Oftalmol. 2012;71(6):358-63.

7. Carvalho KM, Minguini N, Alves MR. Detecção e tratamento dos erros de refração no grupo etário de 0 a 6 Anos. In: Alves MR, Nishi MI, Carvalho KM, Ventura LM, Schellini SA, Kara-José N. Refração ocular: uma necessidade social. Rio de Janeiro: Cultura Médica; 2014. p. 55.

8. FerrazFH, Hirai F, Schellini SA. Estimativas da magnitude e do custo da correção da baixa visão por erro refracional não corrigido no Brasil. In: Alves MR, Nishi MI, Carvalho KM, Ventura LM, Schellini SA, Kara-José N. Refração ocular: uma necessidade social. Rio de Janeiro: Cultura Médica; 2014. p. 35.
9. Organização Mundial da Saúde. Doenças do olho e anexos. In: Organização Mundial da Saúde. CID-10: classificação estatística internacional de doenças e problemas relacionados à saúde. São Paulo: Edusp; 1993. v.1.

10. José NK, Gonçalves ER, Carvalho RS. Olho no Olho: Campanha Nacional de Prevenção à Cegueira e Reabilitação Visual do Escolar. Rio de Janeiro: Cultura Médica; 2006. p. 159-64.

11. Laignier MR, Castro MA, SÁ PS. De olhos bem abertos: investigando acuidade visual em alunos de uma escola municipal de Vitória. Esc Anna Nery RevEnferm. 2010;14(1):113-9.

12. Bertoldi J, Nandi FR, Nunes HK, Trento V, Rosa IM, Almeida JC, et al. Avaliação da prevalência de baixa acuidade visual de alunos do ensino fundamental de uma Escola Municipal da Região da Vila C de Foz do Iguaçu-PR, Brasil. [s.l.] 2009 [citado 2015Abr29]. Disponível em: http:/ /www.foz.unioeste.br/ eventos/sepecel/artigos_sepecel_2009/ enfermagem/Oscar\%20Nihei\%20et\% 20al.pdf

\section{Corresponding author:}

Mário Genilhu Bomfim Pereira

Avenida Olegário Maciel, 143, sala 101 - Centro

ZIP Code 35300-000 - Minas Gerais (MG), Brazil

Phone: (33) 999550506

E-mail: m.g.bomfim@gmail.com 